\title{
Political Geography of Empire: Chinese Varieties of Local Government
}

\section{DANIEL KOSS}

Ruling large expanses of terrain, imperial Chinese state-builders deployed bureaucratic resources sparingly, explicitly defining administrative priorities for county-level jurisdictions. Supported by primary evidence from the Qing dynasty (1644-1911), this article investigates where exactly the empire placed its priorities, what their effect was, and how rational the system was. The empire's priorities were the product of manmade spatial organization, defying macro-regional center-periphery divides, patterns debated in past issues of this journal. Moreover, even when priorities were biased, outdated, and manipulated, they had tangible effects on local state presence, creating distinct bureaucratic spheres: the many non-prioritized routine counties tended to have smaller governments with more first-time magistrates, whereas priority counties typically had bigger governments led by magistrates who were chosen in a deliberative yet corruptible process. The construction and uses of the empire's mental map demonstrates the merits and vicissitudes accompanying the still ongoing Chinese practice of differentiated local government.

C TATE-builders Seek homogeneity of institutions, ideology, and ritual to foster the State's cohesion and empower central authority. Yet clearly, a state that is uniformly powerful throughout a homogenous realm is a utopian ideal. Thus, a central challenge for state-builders is to construct standards that reduce complexity and allow the state to deal with diversity (Scott 1998, 2). Chinese state-builders, ruling over or aspiring to rule over a vast and diverse territory ever since the emergence of a unified state in 221 BCE, were well acquainted with the challenges of standardization. Behind a thin veneer of orthodoxy and orthopraxy, they tolerated a wide array of local beliefs and customs (Sutton 2007, 7). Problems of creating uniform standards to accommodate diversity were particularly tangible in the imperial bureaucracy. This article analyzes how the great variety of local challenges factored into administrative strategies under the Qing (1644-1911), China's last dynasty and one of its longest-lasting. Unable to cover the realm with a uniform blanket of government, Emperor Yongzheng (1722-35) developed an intricate and formal system to prioritize some local jurisdictions over others, attaching combinations of four post designations to all county-level jurisdictions. Despite incentives for institutional corruption and inertia built into the system, the ability to differentiate local government in a rational way was a powerful instrument in the toolbox of 
Chinese governing techniques; and remains a continuing source of state strength till today.

This practice of differentiating governance raises important issues in political science as well as Qing history. Until recently, the state-building literature in political science has given scant attention to subnational variation in state strength (Tsai and Ziblatt 2009, 2), let alone rulers' strategic skill in coping with such variation, with some notable exceptions (Boone 2012). Some scholars have argued that state-building success can be measured as the evenness of state control. ${ }^{1}$ In this view, state-building success is a question of how much territory is brought into the ambit of the fully governed realm according to standardized rules. However, given the impossibility of evenly penetrating a large territory, state-building success is also a question of how well states cope with enduring differences, a point that tends to be overlooked. This article presents the case of late imperial China as a corrective, analyzing how state-builders skillfully managed limited power resources to cope with locally uneven political challenges. Differentiation was a central feature of Qing local administration, enshrined in a system of post designations, which were labels attached to local jurisdictions. So far, Qing historians have barely ventured beyond preliminary explorations of this differentiation system (Guy 2010, 99-101; Skinner 1977, 314-22), partly because their concern was the "typical county" (Qu 1962; Watt 1972) rather than differences among counties. Exceptions include work on the institutional origins (Liu Zhengyun 1993; Zhang Zhengguo 2012) and a statistical analysis (Masui 1999/2000) of the differentiation system. Across this literature, two questions, fundamental for understanding Chinese state-building, have largely been overlooked: First, how did Qing rulers determine their priorities? Second, what difference did priorities make on the ground? Exploring these questions, this interdisciplinary article combines archival evidence with methods of process-tracing and descriptive statistics.

My archival material includes palace memorials concerning the deployment of officials, routine memorials assessing local political challenges, and personnel files. To the extent that the archival material reflects decision-making at court, the goal is to be exhaustive. However, to understand not only the rules, but also the practice, the article moves from central to local politics, in the process becoming more selective in its evidence. Despite advances in digital technology, it is still extremely time-consuming to reconstruct the careers of local officials and to trace changes in post designations over two centuries. Thus I limit myself to the counties ${ }^{2}$ of Shandong Province, a well-studied (e.g., Esherick 1987, 1-37) and diverse set of jurisdictions, sufficient to uncover disjunctions between rules and practice. While provincial-level politics in Shandong are special in that they revolve around the Grand Canal, most of its counties do not border the canal. While specific findings, such as the exact timing of when priorities were adjusted, do not apply to other provinces, institutional dynamics were similar throughout China: Far beyond well-known legal differences (Brunnert and Hagelstrom [1911] 1960, entry 847), priority counties that had been identified as deserving special attention from higherlevel authorities were distinct from the other, routine counties in both the intensity and the quality of government.

\footnotetext{
${ }^{1}$ For this approach and alternatives, see Soifer (2008, 242).

${ }^{2}$ Counties in this article mean both districts (xian 縣) and departments (zhou 州).
} 
This article is organized as follows: The first part analyzes the construction of governing priorities. It begins with challenges in personnel administration, to which the priorities were a rational-bureaucratic response. In so doing, it reveals the limits of the priority system, especially institutional inertia and built-in incentives for corruption. As the second part shows, a county's priority status had important implications for local state presence. After recapitulating and amending what is commonly known about appointment procedures, the second part shows that priority counties were rarely governed by novices, that the procedure for appointing magistrates to priority counties was much more deliberative than scholars have hitherto assumed, and that priority county governments had a larger size than ordinary counties. The article demonstrates the logic by which Qing state-builders formulated and then acted upon governing priorities, to achieve rational government, tailor-made to local challenges. Yet it also reveals that inertia and venality remained two insurmountable obstacles in the Chinese state-builders' quest for efficient rationality.

\section{Institutionalizing Governing Priorities}

G. William Skinner's macro-regional approach, an influential theory of the fundamental socioeconomic geography of China throughout time, suggests that geographic factors beyond the control of state-builders largely explain the reach of the Chinese state. According to Skinner's macro-regional approach, topographically determined drainage systems constituted physiographic macro-regions, which in turn shaped socioeconomic macro-regions (Skinner 1985, 280). Through geographic and statistical analysis, Skinner identified the cores and peripheries of nine macro-regions, arguing that they were highly stable over time and gave a distinctive spatial structure to the Chinese polity. If Skinner is right, the Chinese state is strong at its cores and weak in its peripheries. Yet state-builders are not always slaves to geography. The Grand Canal, constructed under the Song dynasty (960-1279) to connect China's North to its South and in use until the nineteenth century, epitomizes how Chinese state-builders reconfigured the empire's political geography in defiance of natural drainage systems. As this article will demonstrate, the allocation of personnel indicates that the priorities of imperial rulers could differ starkly from what one would expect under the macro-regions paradigm. In many cases, the court sought to establish a robust civilian presence in peripheral counties, if their vital importance to the empire and the challenges arising from the local population were deemed to warrant such presence. The history of Chinese state-building is at least in part a history of state-builders overcoming geographically predetermined patterns.

To see the sharp contrast between state-building along macro-regional patterns versus state-building against macro-regional patterns, consider the two maps. Figure 1 depicts macro-regional cores (dark colors) and peripheries (light colors) of parts of China. Figure 2 shows a political map of the empire, representing the court's administrative priorities: Black are top-priority counties (four post designations), and the lightest grey are routine counties (no post designations). Comparing the two maps, one notices that the expected congruence between macro-regional systems and governing priorities is tenuous. For instance, the vast, light-colored area extending between Northern Anhui, 


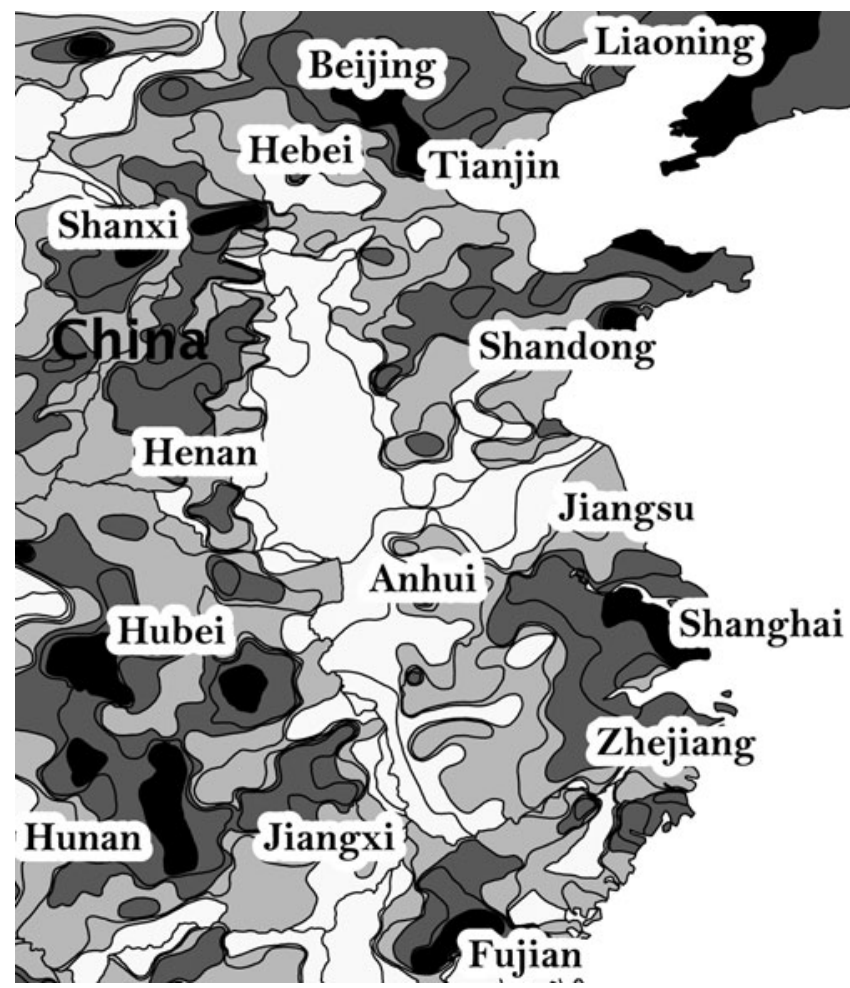

Figure 1. Map based on Skinner's classic socioeconomic macro-regions model. Dark areas are cores and light areas peripheries. Author's map. Data from Skinner, Yue, and Henderson (2013).

Henan, and Shandong (see figure 1) is the peripheral Huaibei area, known for its "legacy of collective violence" (Perry 1980, 10). Yet in contrast to what one would expect from the macro-regional approach, the Qing court did not simply abandon this area. To the contrary, an unusual cluster of a dozen or so counties was designated as high priority, precisely because of rebellious populations. The following sections analyze why Qing rulers decided to formally evaluate their realm and determine priorities.

\section{Rationalizing the Personnel Appointment System}

Emperor Yongzheng was the first Qing ruler to institutionalize governing priorities. Carefully designed and highly formalized, the resulting post designation system carried the imprint of its rational-bureaucratic founder. Seeking to thoroughly evaluate all local positions in the empire, the project reflected this emperor's ambitious vision of a proto-modern, strong imperial state (Thornton 2007, 22). From the start, governing priorities were a tool for personnel selection, since Emperor Yongzheng saw capable local officials as the key to improving local government (Wang 2007). He doubted the efficacy of selecting officials through the examination system, which guaranteed individuals a post if they passed the highest level of an exam that tested familiarity with Confucian ideas. Yet Yongzheng could not simply impose new appointment procedures for all positions. Such 


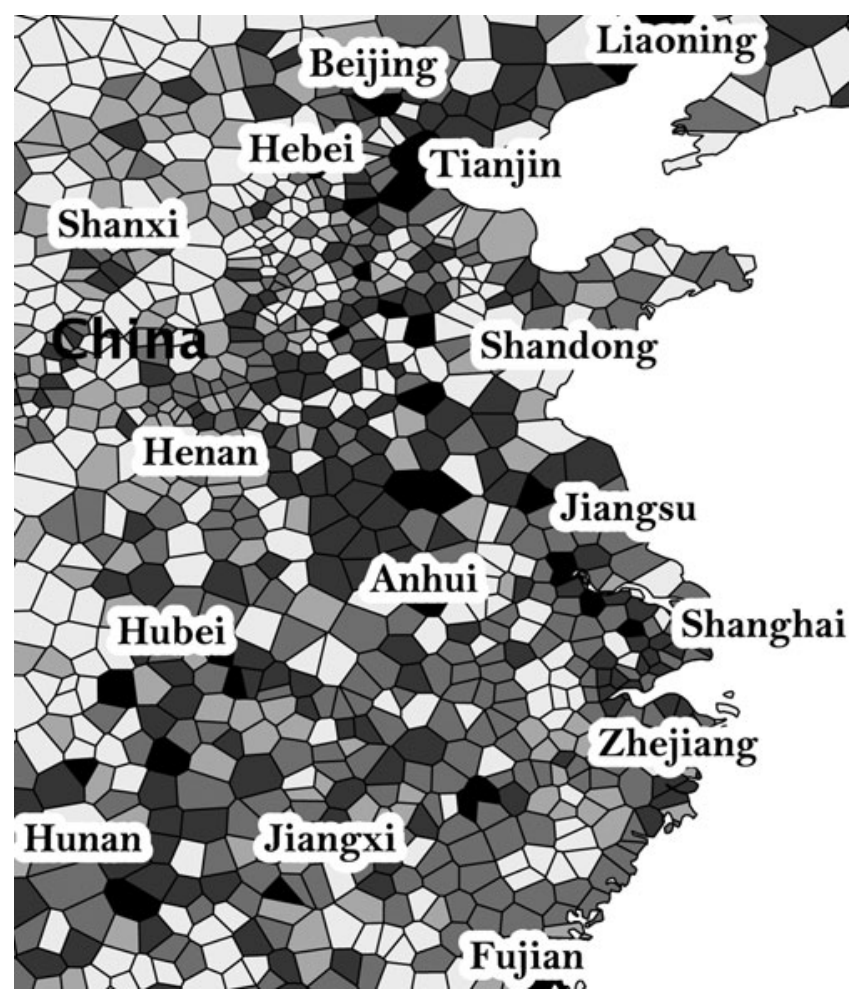

Figure 2. The Qing court's priority map. County boundaries are approximated as Theissen polygons, derived from the location of county seats. Author's map. Data from Yue, Skinner, and Henderson (2007).

a move would have alienated the literati, who saw it as their traditional right to be appointed to office, even after a long wait, once they passed the highest-level imperial examination. Yongzheng's reforms of personnel selection, which culminated in the post designation system, were a way to rationalize the procedures for appointing officials, at least for those localities that were of vital importance to the empire.

When Yongzheng ascended the throne in 1722, the magistrate appointment system was in crisis. After the establishment of the Qing dynasty in 1644, posts had been filled in an ad hoc manner, flexible enough to reserve posts in strategic and unsettled localities for officials known to be loyal to the new Manchu rulers. In the case of Shandong, at the time 25 percent of all district magistrates were either Manchu or from Liaodong in Manchuria (I and Fogel 1981, 5). Under Emperor Kangxi (1661-1722), formal yet inflexible regulations came to determine personnel selection: the Board of Personnel kept lists of degree holders, office purchasers, and officials up for promotion, who were assigned to their posts by drawing lots. The procedure was bound to result in mismatches between officials and their posts. Mismatches in vitally important locales could have deleterious repercussions for the empire as a whole. In exceptional cases (e.g., NPM 402004677), governors asked permission to handpick officials - a cumbersome procedure that required the emperor's approval and did not resolve the problem of novices administering vitally important jurisdictions. 
Yongzheng responded to this urgent functional need by setting aside priority posts, to be exempted from the mechanical appointment procedures of the Board of Personnel. Henceforth the provincial governor would appoint county magistrates to these localities. The first round of exemptions came in 1723, marking certain localities along waterways, the empire's lifelines, especially key stations along the Grand Canal; a second round of exemptions marked counties along the seashore as priority counties (Yun 1764, 8:39, 8:45). The fact that Yongzheng adopted these measures less than a year after ascending to the throne suggests that court officials had been considering such exemptions before, but found no support from Kangxi. Even if assignments through lotteries had the advantage of curbing court intrigues, such indiscriminate bureaucratic procedures could not do justice to the diversity of the empire.

\section{Toward a Mental Map of the Empire}

Which counties were most in need of carefully chosen magistrates? Since it was not politically feasible to abandon the established job lottery system altogether, the empire needed to carefully weigh its priorities. Marking counties along the seashore as priority counties was a contestable choice, since many of them did not fit conventional notions of important counties. Yongzheng needed less ad hoc criteria to reliably target important counties. Functional needs to classify counties had arisen before, so the court could draw on institutional solutions from previous dynasties. The Tang dynasty (618-907) had categorized counties according to population size as top (shang 上), middle (zhong 中), and low (xia 下). The Ming dynasty (1368-1644) had ranked counties based on tax revenues (Nimick 1999, 45). In this tradition, Yongzheng ordered provincial governors to determine the degree of importance of local positions, including the almost two thousand county magistrate posts. ${ }^{3}$

Shortly thereafter, we see a rare case of bureaucratic innovation that can be traced to the creativeness of a single individual: Jin Hong 金鉷, the inventor of the post designation system, who had recently been appointed Provincial Administrative Commissioner of Guangxi Province. His position was far away from the levers of power, but came with an important prerogative. Jin Hong could memorialize directly to the emperor, and the seal of his memorial could only be broken in the presence of Yongzheng himself. Inspired by this prospect, Jin sent a series of bold memorials to Beijing soon after taking office. When Jin Hong's memorials arrived in the capital, newly compiled lists of importance ratings had already begun trickling in from throughout the empire, such as one from Shandong in January 1728 (Yongzheng chao neige liuke shishu 2002, 1:39, 561). Yet Jin Hong's ambitious plan impressed Yongzheng so much that he suddenly changed course, moving from the four-letter scale of importance ratings to the more complex system of post designations. ${ }^{4}$

Concerned about the frequent mismatches between local officials and their posts, Jin Hong had suggested flagging particularly challenging counties, using one or several of four post designations as labels. In his enthusiastic endorsement, Yongzheng expressed

${ }^{3}$ The imperial edict is lost, but its content is known, since governors cite the original (Yongzheng chao neige liuke shishu 2002, 1:39, 561).

${ }^{4}$ NPM 402008352, by Guangxi Provincial Judge Guo Hong (Jin Hong), Yongzheng 6/3/19 (1728). For a reprint with transcription, annotations, and explanations, see Liu Zhengyun (2012, 133-47). 
regret that importance ratings had been assigned in an arbitrary manner and instructed the Board of Personnel to study how post designations could be used in the future as a basis for importance ratings. Slow to respond, the Board rolled out the post designation system in 1732 (Liu Zhengyun 1993, 183). Characteristically for the Qing state, the outdated institutions, including waterway tags, seashore tags, and importance ratings, were not abandoned but were gradually incorporated into the new system. This reform process left a long paper trail in the archives, indicating that the post designation system had become the gold standard to which previous priority markers had to adjust (e.g., FC 02-01-03-03942-008).

What kinds of counties deserved priority? The priority of a county was reflected in the number of post designations, to be assigned following Jin Hong's definitions: "CHONG 衝 (thoroughfare): places at busy highways. FAN 繁 (troublesome): places with numerous and complex official business. PI 疲 (wearisome): places prone to tax arrears. NAN 難 (difficult): places where the population is wicked, where customs are violent and where cases of theft are numerous" (NPM 402008352). These definitions struck a chord with Yongzheng, because the four terms concisely reflected familiar concerns in the area of personnel selection and promised to put counties' priority rankings on a more objective footing. To be sure, Jin Hong's nominal definitions of the coding scheme seem ambiguous. Yet in practice, officials in China shared an understanding as to what each of the tags meant, far beyond Jin Hong's initial definitions. When governors transferred an official to a priority position, they often elaborated on the nature of the post, going well beyond the mere post designations and displaying a common interpretation of post designations. This is similar to other areas of the Qing dynasty's bureaucracy, where miscommunication was surprisingly rare despite the technical and definitional challenges (Metzger 1973, 129).

Similarly, when provincial governors argued for adjustments of post designations, they described why a county should be subsumed under certain designations. A governor of Shandong in 1782 argued for adding a NAN tag to the existing two tags of Ziyang County: ${ }^{5}$

I investigated Ziyang County in Yanzhou Prefecture. Originally the county was assigned a CHONG and FAN, and was a post of middle importance with the magistrate appointment privileges going to the Board of Personnel. The county is the most important place next to a prefectural seat. Military forces are stationed there. Relations between the soldiers and the civilians are complicated and must be appropriately controlled at all times. Moreover, customs are rough and violent. Tax arrears. Lots of official business. There are two rivers flowing through the county. Maintaining embankments, dikes and bridges is not easy. A busy road passes through the county. Postmasters are stationed in Xinjia and Changping, and their unfailing supervision is of strategic importance. (NPM 403042055)

On the one hand, reasons for assigning post designations were diverse. The problem of civil-military relations evidently critical for Ziyang County was not widely shared by

${ }^{5}$ The map in figure 5 shows the counties mentioned in the article. 
other counties. But the prevalence of violent customs and the challenge of maintaining hydraulic works and imperial lines of communications were among often-cited reasons for why a post should be considered important.

Skinner suggests that we cannot take the post designations literally, because they leave out a "secret strategic component." His conjecture is based on the observation that the fit between post designations and importance ratings was less than perfect (Skinner 1977, 317ff). In reality, such inconsistencies are satisfactorily explained as the result of a simple numerical incompatibility: the number of post designations put counties into five groups (between zero and four designations), but the importance scale had only four levels, leading to ambiguities (Zhang Zhengguo 2012, 388-93). In addition, when determining the priority status, bureaucrats took some liberties to accommodate preexisting river and seashore tags into the new system. Even more mundane, surviving files of the Imperial History Office reveal the difficulty of keeping accurate records. For Caozhou Prefecture, a compiler recorded a CHONG-tag instead of a PI-tag, a mistake that was caught (NPM 2050000414). Other mistakes found their way into the definite compilations (Liu Zhengyun 1994). Skinner ascribed too much rationality to government behavior. Inconsistencies reflected bureaucratic imperfections rather than grand strategy.

The existence of a secret strategic component also appears implausible for substantive reasons. Post designations were assigned in a decentralized way. To keep the system consistent and operational, field administrators had to be informed of its fundamental operating principles. Security secrets would typically be revealed in the inner court communication system, especially in palace memorials to the emperor (Bartlett 1991). Both in the inner and outer court communications, we find much discussion of post designations, but no indication whatsoever of any hidden component. We also need to take into account that the system was designed to guide civilian personnel appointments and as such would not have been focused on military defense, as Skinner suggests. Finally, to judge from the imperial rescript on the memorial by Jin Hong, the grand purpose of the system was not to obscure and hide, but rather to illuminate and make transparent the empire's governing priorities, so as to allow a solid, rational assessment of where scarce bureaucratic resources should best be deployed.

\section{Governing Priorities: Dynamics of Change}

Priorities needed to be adjusted over time. Qing officials recognized that poorly updated priorities were detrimental for local government. The Shandong governor expressed this consensus in a memorial of 1782 , using a set of widely used phrases:

Among the 110 districts, departments and garrisons [in Shandong], there are many where local conditions in the past and local conditions today are not the same. The importance ratings of such positions should be adjusted. One should go with the times and make changes. For the sake of good government.... If we swap importance ratings [in the way outlined above], each place would end up with an appropriate label, human resources would be allocated according to local conditions and it would be to the benefit of local administration. (NPM 403042055) 


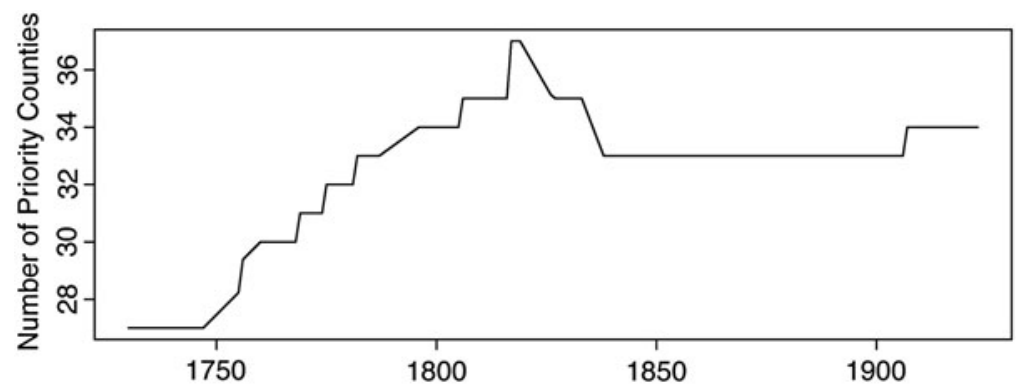

Figure 3. Slow institutional change in Shandong.

Governors in other places made similar assessments, even if the transformations of the physical and human geography in Shandong may have been more radical than elsewhere. The dramatic shift in the course of the Yellow River, the drastic decline of the Grand Canal, and Western imperialist intrusion along the coast were important transformations, which presumably should have been reflected in shifting governing priorities. But in reality, institutional change was slow.

To analyze shifting priorities, I have assembled an events database of post designation changes in Shandong. I identified changes by comparing different editions of the frequently updated Lists of Official Positions (also called Red Books), using a recent multivolume compilation (Qingdai jinshen lu jicheng 2008). To determine timing, I used memorials on post designation changes, found in archives in Beijing and Taipei, supplemented by the Veritable Records of the Qing Dynasty. For most instances of change, this method allows for determining an exact year of change. For other shifts, I can only give a range, which on average is four years. The greatest uncertainty concerns the twelve years between 1748 and 1760, as well as the earliest years of the system, when post designations were not yet recorded in the Lists of Official Positions.

The number of counties for which the governor held appointment privileges varied over time (see figure 3). It included counties with three or four post designations, as well as counties for which the governor held appointment privileges by virtue of a river tag or maritime tag. The number of priority counties had been continuously expanding since 1730 and reached a peak in 1800, when thirty-nine counties fell under provincial jurisdiction, reflecting an expansion of the power of governors in the second half of the nineteenth century. By contrast, the stasis in the nineteenth century indicates that governors had lost interest in expanding formal appointment powers, since they had alternative ways to dominate local appointment procedures (discussed below). Over the entire time period from 1720 to 1912, institutional change was gradual and slow.

Figure 3 is a balance sheet. It misses cases where post designations were updated by swaps: downgrading a previously important county and at the same time upgrading a previously unimportant county. Counting all adjustments (see figure 4), I found that there were three bursts of adjustments. Upon close inspection, it is clear that the politics behind each of the three peaks was quite different. The first peak-apart from ongoing attempts by provincial governors to expand their authority-reflected measures to make the post designations consistent with preexisting appointment privileges. For instance, Qufu's magistrate had customarily been appointed through a special procedure 


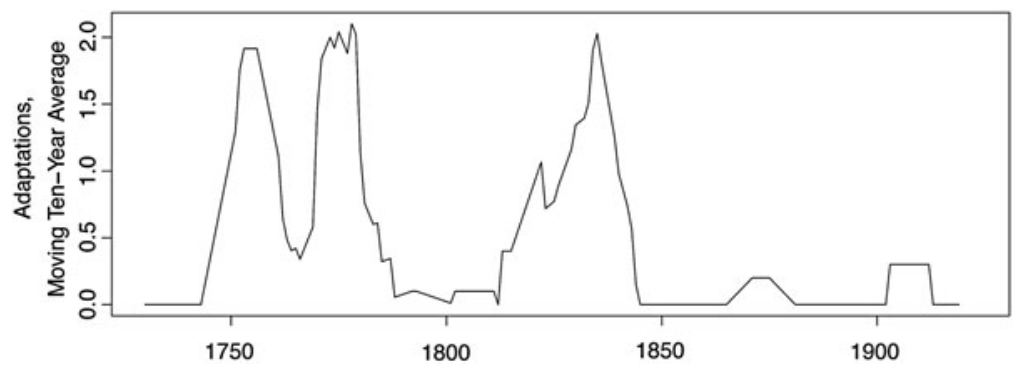

Figure 4. Three episodes of adaptation in Shandong.

in consultation with the Confucius family. To regularize this exception, in 1756 Qufu was upgraded to a priority county, arbitrarily adding three post designations (NPM 403011862). Similarly, post designations were added to counties with river or seashore tags (FC 02-01-03-03942-008). The second peak was part of a corruption scheme, as explained in the next section. The third peak stood at the end of what appear as aimless adjustments of post designations in the first half of the Daoguang reign. Most adjustments since 1820 were inconsequential: It was a change of labels, but rarely a change of priority status. Presumably, the emperor wanted institutional adjustment, but bureaucrats only carried out superficial changes. Even worse, most adjustments were later reversed. Only the post designations of six counties were permanently altered. For example, Jiaozhou was downgraded to a routine county, although the county was turning into the frontline of Western colonial expansion into Shandong. The peak around 1834 represents the moment when a series of prior, aimless changes were reversed and permanent changes were made that turned a blind eye to the colonial challenge.

In sum, by the early nineteenth century (well before the third burst in figure 4), governing priorities had ceased to adjust to rapidly evolving local conditions. As a result, they were increasingly out of sync with China's socioeconomic realities. For Shandong, the most striking mismatch was the high priority continuously accorded to counties along the Grand Canal, at a time when this region had turned into a hinterland (Pomeranz 1993, chap. 4). Yongzheng's proto-modern attempt at institutionalizing priorities for China’s civilian government came with a formidable disadvantage. Once formalized, priorities became sticky and hard to change. Frozen in time, the institution took on a life of itself. Modernizing institutionalization had the unintended side effect of bureaucratic stagnation.

\section{Corrupted Priorities and the Empire's Faulty Mental Map}

Governors and their entourage played an important role in defining local governing priorities. After all, it was not the court in Beijing, but the field administration that had sufficient information to assess the shifting importance of counties. Did governors advocate changes with the best interest of the state at heart, or did they exploit the asymmetric distribution of information? Governors sought to secure as many positions as possible, but officials at the Board of Personnel knew how to protect their turf and prevent priority inflation. More importantly, for the sake of their own careers, governors were well advised to have capable officials administer vitally important counties. If incompetent 
magistrates were in charge of, say, regulating water levels of the Grand Canal, a governor could not put his heart at rest, because he himself would be held responsible if transportation routes to Beijing were interrupted as a result of local mismanagement. To gain appointment powers over such vital localities, governors had reason not to misrepresent the importance of counties in their jurisdiction. In this sense, governors had incentives to truthfully report governing priorities.

On the other hand, the imperial personnel system was a quagmire of corruption. Government positions were legally up for sale through the central authorities in Beijing (L. Zhang 2010, 7). For provincial governments, without special permission, it was illegal to sell offices. Yet when Beijing gradually divested itself of appointment powers, which came to rest with provincial governments, money sought to buy access to power in the provinces. This was the institutional background of an extortion scheme that led to the dismissal and death sentence of Shandong governor Guo Tai 國泰 in 1782. Kent Guy $(2010,192-98)$ has demonstrated that the scandal was closely connected to the governor's appointment prerogatives. The example of one ordinary county magistrate involved in this scheme, Chen Juecheng, shows the quid pro quo, as money was paid in return for positions. For his promotion to the magistracy of $\mathrm{Pu}$ County, after seeing the emperor, Chen needed an endorsement by the governor and entrusted 1,000 taels of silver to the prefect of Jinan, who acted as the middleman, bought a jade table plaque, and delivered it to the governor (Yu and Zhang 1994, 2465). Guo Tai promptly sent a memorial to the throne, making an argument that Chen was the right person to serve as a magistrate of Pu County (NPM 022811). Chen then paid 1,000 tales of silver in cash, euphemistically referred to as a "fee to support the masses" (Yu and Zhang 1994, 2446). In short, the governor knew how to use his power in an openly transactional manner to extract money from Chen.

Provincial office sales had repercussions on the post designations. Some counties at the heart of the corruption scandal had been raised to priority status after Guo Tai became Shandong's Surveillance Commissioner in 1771, an influential position in the provincial administration. Especially since 1772, when Guo Tai was promoted to the position of provincial judge, Shandong's second-most powerful official, a wave of memorials from that province asked for the adjustment of post designations. Indeed, the magistracy of $\mathrm{Pu}$ County bought by Chen had been elevated to priority status in the 1770s. Guo Tai not only sold offices, but also changed post designations, hoping to gain appointment privileges over desirable positions that would sell at a higher price. Once Guo Tai was promoted to provincial governor, he asked to turn Gaotang County into a priority post (NPM 029516). At that point, the Board of Personnel faced him down, calling upon the emperor to intervene. Henceforth, Guo Tai was allowed to upgrade counties only while downgrading others (NPM 026062). Since then, Guo Tai's modus operandi was to upgrade counties in wealthy areas along the Grand Canal and downgrade counties with a seashore tag in the then less affluent eastern part of the province.

The long-term distortive effect of Guo Tai's manipulations on the governing priorities in Shandong was considerable. Fifteen adjustments of post designations are linked to Guo Tai's tenure in Shandong, largely explaining the second wave of adjustments in the 1770s (compare figure 4). Even if a highly disruptive peasant rebellion of 1774 may have justified more attention to Liaocheng Prefecture (Naquin 1981, 180n42), it is hardly plausible that the area permanently needed particularly qualified magistrates 


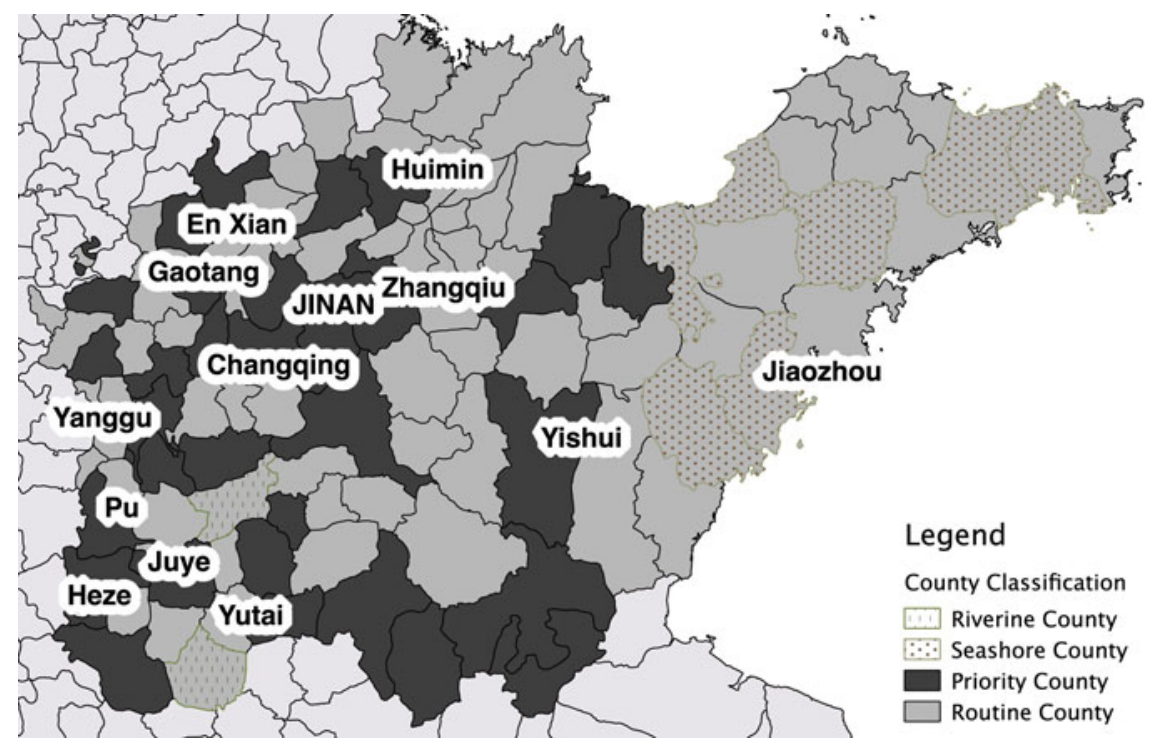

Figure 5. Shandong, highlighting counties mentioned in the text. The priority classification is as of 1800 , after Guo Tai's manipulations. Seashore counties had lost their priority status. Note the cluster of priority counties in the northwest.

for half a dozen counties, all within a short distance of each other (see map, figure 5). Moreover, upgrading could be radical, as in the case of $\mathrm{Pu}$ County, which went from no post designation to three post designations. It appears that Guo Tai concentrated priority counties in Liaocheng, not only because the area was unusually wealthy, but also because he could then run his extortion scheme through one or two loyal prefects, instead of involving prefects throughout the province. Since many of Guo Tai's adjustments were never cancelled after his fall from power and execution, his operations distorted the empire's map of governing priorities for the remaining 150 years of Qing rule. The court in Beijing perceived its realm through biased lenses.

\section{A Governance Rift Dividing the Empire}

The priority map was not an empty letter. It guided crucial government decisions and had far-reaching effects on local administration. Prominent documents of the Qing dynasty refer frequently to post designations, indicating that at the time administrators and historians alike recognized post designations as an essential tool of Qing statecraft. The geography section of the Qing Dynastic History (Draft Version), for example, began the entry for each county with its post designations. Even more telling, since the mid-eighteenth century the empire's frequently updated List of Official Positions began each entry with the jurisdiction's designations. Since these lists were compiled for the practical needs of officials, the inclusion of post designations reflects their relevance for routine bureaucratic life. The most tangible evidence that the importance ratings were on the minds of officials in their day-to-day decision-making comes from Board of Personnel files. In these files one discovers post designations noted in the 


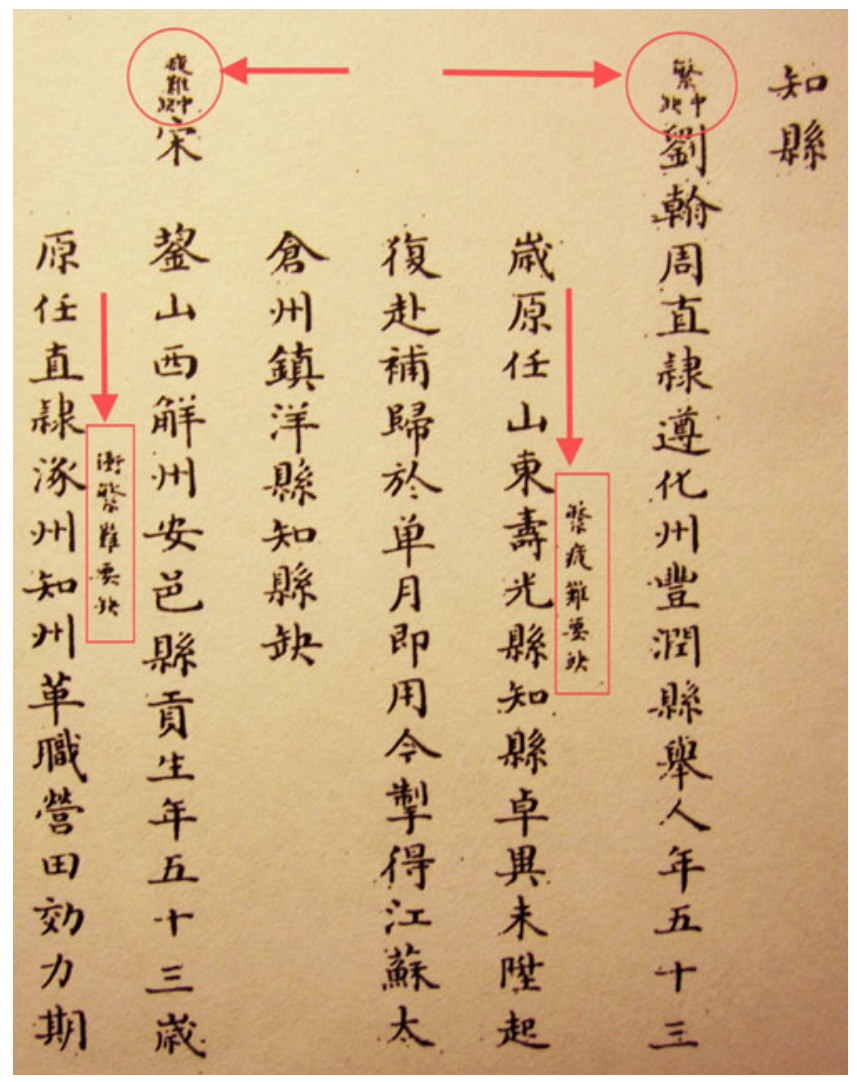

Figure 6. Post designations, Board of Personnel files, 1804 (Qin, Tang, Ye, and Zhang 1997, 24:136).

margins in small script. For example, the files documenting monthly appointments regularly provide post designations for each position filled (compare figure 6). Occasionally, memorials to the emperor include post designations, written between the lines of the main text (FC 02-01-03-08323-011). Far from being an obscure typology of interest only to imperial geographers in an ivory tower, post designations were heavily used by administrators, especially at the Board of Personnel.

\section{Appointment Procedures for County Magistrates}

To demonstrate the effect of post designations in the domain of personnel management, it is first necessary to recapitulate and amend what is known about official appointments under the Qing. Misled by Qing legal regulations, as opposed to bureaucratic practice, a scholarly consensus has endorsed John Watt's $(1972,48)$ view that "the appointments to the great majority of the district posts were under the sole management of the central authorities." According to Watt (46), the Board of Personnel made appointments to 944 districts, that is, about 70 percent of the total, each month compiling a list of twenty-three individuals and then drawing lots to assign these individuals to districts throughout the empire. In theory, the monthly lists could match the number of job vacancies only if magistrates on average served for three and a half years. 


\begin{tabular}{l|ccccc}
\hline \hline & Qianlong 15 & Jiaqing 3 & Jiaqing 4 & Jiaqing 5 & Daoguang 30 \\
& 1750 & 1798 & 1799 & 1800 & 1850 \\
\hline 1st month & $\cdot$ & 0 &. & 6 & 5 \\
2nd month &. & 7 &. & 20 & 7 \\
3rd month & 19 & 8 &. & 8 & 1 \\
4th month &. & 6 & 6 & 5 & 8 \\
5th month &. & 6 &. &. & 5 \\
6th month & 21 & 9 &. & 3 & 3 \\
7th month & 11 & 7 & 6 & 8 & 5 \\
8th month & 0 & 6 & 4 &. & 6 \\
9th month & 0 & 5 & 8 & 1 & 10 \\
10th month & 0 & 4 & 5 & 4 & 5 \\
11th month & 18 & 13 &. & 5 &. \\
12th month & 13 & - & 7 & 12 & 61 \\
\hline YEARLY SUM & 82 & 71 & 36 & 72 & 5.5 \\
MONTHLY AVERAGE & 10.3 & 6.5 & 6 & 7.2 & \\
\hline \hline
\end{tabular}

Figure 7. Magistrates assigned through the monthly lottery (by month).

In practice, the system could not have functioned as commonly believed, since the appointments through the monthly lottery fell far short of the number of vacancies. First, magistrates on average served less than three and a half years, as they were often afflicted by disease, required to go into mourning, or otherwise induced to end their term prematurely, for example, as a result of punishment. ${ }^{6}$ Second, according to the records of the Board of Personnel, monthly selections on average assigned far fewer than twenty-three individuals. The monthly selections of 1750 on average assigned just ten magistrates, so that at most 33 percent of all magistrate appointments were through the Board of Personnel and its monthly selections (figure 7; Qin et al. 1997, vol. 16/17). This rate declined to 22 percent by 1800 (figure 7; Qin et al. 1997, vol. 23), and to 18 percent by 1850 (figure 7; Qin et al. 1997, vol. 25), indicating that the monthly selections gradually lost their importance.

A little-known analysis of Qing governance from 1899 by the British Consul-General Byron Brenan confirms these findings. In contrast to the well-known account of Chinese institutions by Brunnert and Hagelstrom ([1911] 1960) from the Russian legation, the British Consul-General describes not administrative law, but administrative practice and provides extraordinarily rich details, including tidbits such as the corrupting influence on officials-in-waiting stemming from their local female domestics. According to Brenan $(1899,3)$, "some officers get their appointment direct from Peking, but more frequently they are sent to one of the provincial capitals to await a vacancy." Similarly, based on a late-Qing commentary, Pierre-Étienne Will $(2002,112 \mathrm{f})$ suggests that "in the nineteenth century at least," the lottery assigned each official not to a county, but to a province, effectively delegating personnel appointments at the district level to the provincial governor.

To grasp procedural practice at a time when the post designation system had become a well-established standard, let us focus on the year 1800. This year provides a good test for studying the effect of the post designation system, for several reasons. First, by that

${ }^{6} \mathrm{I}$ am not aware of a numerical summary of all the different incidents that tended to interrupt a Qing official's career. On sick leaves, see He (2012), and on mourning, see Kutcher (1999). 
time the system had been in use for over half a century and had become routine. Second, the year is a particularly hard test, because personnel management was affected by various crises characteristic of the Qing bureaucracy: even more than the large "anti-corruption campaign" rolled out at the time-whose effect was less noticeable at the district level-standard operating procedures were under pressure because the Board of Personnel needed to assign 157 county magistrates who had bought office in 1798 (L. Zhang 2010, 65, 280). Thus, that year provides a hard test case.

One hundred seven county magistrates served in Shandong in 1800. The Shandong gazetteer provides almost all their names (Sun et al. 1915). A variety of sources, especially routine memorials to the Board of Personnel (AS, FC), help us to identify their paths to office. Less than half of these magistrates arrived in their office through one of the two well-known career paths: 27 percent of these magistrates had been transferred to priority districts, and 21 percent had been assigned by the central lottery. But strikingly, the remaining 52 percent of appointments fit neither procedural category. One procedure that stands out for its frequency involves the policy of "Great Selection (Grade 1)" (Datiao Yideng 大挑一等). Introduced in 1752, this policy had the Board of Personnel select provincial degree holders for a fast track that guaranteed immediate employment with a prospect of soon attaining a county magistrate position. ${ }^{7}$ After an imperial audience, the individuals on the fast track drew a lot that assigned them not to any specific position, but simply to a provincial governor's office. This practice avoided the long wait for an actual position to open up. In the provincial capital, the officials on the fast track carried out ad hoc assignments, thereby gaining experience and proving their talent. At his own discretion, the governor would then memorialize the court to propose the transfer of the official to a proper position. ${ }^{8}$

By 1800, most appointments were no longer dependent on a random lottery, but on the provincial governor's decision. Did the post designations guide his exercise of discretion? Did governors feel committed to the rule that magistrates of priority counties must have previously held an official position? Or were governors content to dispatch officials who had proven their qualities on assignments during their time as officials-in-waiting in the provincial capital? Given how far the appointment system had moved away from the initial institutional setting of the early eighteenth century, whether post designations continued to affect local government at the beginning of the nineteenth century is an empirical question to which I turn next.

\section{Keeping Novices Away from Priority Posts}

One original purpose of the post designation system was to avoid having magistrates with no prior experience occupy important posts. A thorough examination of each of the 107 county magistrates in Shandong of the year 1800 reveals that only 20 percent of the magistrates in top-priority positions and only 32 percent of the magistrates on three-tag

${ }^{7}$ There was also “Great Selection (Grade 2)" (Datiao Erdeng 大挑二等), but the career goal was not to become a magistrate.

${ }^{8}$ Examples for this career path include: (1) NI Qiwang to Changshan, FC 02-01-03-08102-005; (2) PENG Shu to Qufu, FC 02-01-03-07634-003; (3) MA Tingxuan to Wucheng, FC 02-01-03-08284-002; (4) ZHANG Binglu to Zhangqiu, 02-01-03-08465-024; (5) REN Zhu to Zou County, FC 02-01-03-08292-002; and (6) LI Qionglin’s to Zouping, FC 02-01-03-07703-018. 


\begin{tabular}{l|ccccc}
\hline \hline experience & no tags & one tag & two tags & three tags & four tags \\
\hline number of counties & 38 & 11 & 23 & 30 & 5 \\
\hline no experience & 25 & 8 & 14 & 9 & 1 \\
1 year & & & & 3 & \\
2 years & & 1 & & 1 & \\
3 years & 2 & & 1 & 3 & 1 \\
4-6 years & 2 & 1 & 2 & 2 & 2 \\
7-9 years & 1 & & 2 & 1 & 1 \\
10-12 years & 1 & & 2 & 2 & \\
13-15 years & 2 & & 1 & & \\
more than 15 years & 5 & 1 & 1 & 4 & \\
unclear & 3.8 & 1.9 & 5.5 & 4.6 & 7 \\
\hline average experience & $66 \%$ & $72 \%$ & $60 \%$ & $30 \%$ & $20 \%$ \\
share of novices & & & & &
\end{tabular}

Figure 8. Experience of county magistrates (Shandong, 1800).

priority posts were novices. By contrast, in routine counties, the share of novices was much higher, well over 60 percent (see figure 8). In that sense, the system helped reduce mismatches between officials and their posts.

To illustrate that routine counties were at a disadvantage in receiving experienced magistrates, consider Juye County, which lost its priority status in 1769 (FC 02-010306360-010). Henceforth, routine selection procedures came to determine the local magistrate with characteristic problems. In 1800, at the monthly lottery outside Tian'anmen Gate, a certain forty-year-old Ma Qipeng from Sha'anxi received an assignment to Juye. Notes on the margins of this lottery record confirm that the county at the time was Pi-Nan, of middle importance (Qin et al. 1997, 23:578). Ma Qipeng was not only lacking experience; he also did not hold a degree. He had been allowed to participate in this lottery because he had bought office and had paid extra to be eligible for an expedited process. While his later promotions suggest that he eventually turned out well as an administrator (AS 115653-001), at the time of his arrival in Juye County, the selection of Ma Qipeng was a risky one. The fact that a non-degree-holding novice was taking over a county along the Grand Canal probably was the reason why the governor in the very same year petitioned to have appointment privileges for Juye returned to the province.

While officials with no experience were rarely found on priority posts, the relationship between the average experience of an official and the importance of a post was nonlinear. Using the same database, I calculated how many years passed from each of the officials' first appointment to the magistrate position held in $1800 .^{9}$ Magistrates taking on a post in a county with four designations were more experienced (seven years on average), but there are irregularities: magistrates in positions with three designations had slightly less experience than magistrates in positions with two post designations. There are several extremely experienced officials serving in the least important positions.

Who were these senior men? Many officials started late and had short careers; or were transferred from magistrate positions in one corner of the empire to another,

\footnotetext{
${ }^{9}$ Ideally, one would subtract sick leaves and mourning periods, but the personnel records do not consistently provide such detail.
} 
without much hope for career advancement (Watt 1972, 76). Some individuals achieved stellar careers recorded in official biographies, such as $\mathrm{Li} \mathrm{Hu}$ who in 1748 began his career with increasingly responsible magistrate positions in Shandong and ultimately became a governor of Guangdong (Guy 2014, 77-80). But there was also a different type of career pattern, which turned a magistrate into the governor's man and into an expert to deal with local challenges in a province. Wang Daoheng was one such official. In 1800, Gaoyuan needed a new magistrate. Although the county was under the jurisdiction of the Board of Personnel, the governor suggested dispatching Wang Daoheng (AS 001370-001), who at the time was seventy years old and had served (with only minor interruptions) in Shandong for forty-three years. Previously he had held very responsible positions, including departmental magistrate positions in Dezhou and Jining, both with three tags. Having served in about a dozen counties in Shandong, Wang Daoheng was known to be "mature, experienced and working earnestly" (FC 02-01-0307750-010). His assignment to Gaoyuan is best explained by the governor's hesitation to assign a senior person to a priority post, both out of respect and out of a concern that he might be physically unfit for such a post. Wang served until 1809, when he asked to be granted sick leave from his assignment in Yidu after fifty-two years in the service of the Qing (FC 02-01-03-08784-017). Late in their distinguished careers, officials like Wang were not assigned to priority counties because, though experienced, such an assignment would have been inappropriate for an elderly official. Novices, as well as the most experienced yet elderly officials, were kept away from priority posts.

\section{The Deliberative Process Leading to Priority Appointments}

In addition to keeping novices away from the most high-priority magistracy positions, the reformed appointment procedure to priority posts approximated a deliberative process, reflective of a rational bureaucracy. To be sure, human discretion also brought corruption, influence peddling, and bureaucratic politics, so we should not idealize the reformed system. But there were some checks and balances. Moreover, provincial administrators had a strong interest in the smooth functioning of the lower-level hierarchy. When Yongzheng and Qianlong gave appointment privileges to governors, they apparently expected the benefits of rationalization to outweigh the damages of corruption.

The case of Yutai County epitomizes the deliberative process that preceded appointments to priority posts. In 1800, the county magistrate position was vacant, since its incumbent had been impeached for irregularities discovered during the triennial inspection. Shandong's governor asked to fill the vacancy by transferring the magistrate of Jinxiang County to Yutai County, but the Board of Personnel did not approve, pointing out the candidate's insufficient job experience. Shandong's governor then turned to the administrative commissioner and the surveillance commissioner of the province to work out a solution. Recognizing that Yutai was an important CHONG-FAN-NAN county along a waterway, they argued as follows:

According to precedence, the position should be locally filled by making a transfer from another county. But among the district magistrates in our province, if we exempt those who are disqualified for disciplinary reasons, as well as those who are now serving in another priority post, there is no official who would be appropriate for the locality in question. At present, there simply isn't 
anyone who fulfills all the requirements expected by precedent. But we found an assistant magistrate, who in this position has already served for more than five years. (FC 02-01-03-08400-024)

The report, later endorsed by the governor and sent to Beijing, goes on to describe the experience and the personality of this candidate, who eventually received the priority position despite the fact that he had experience only as an assistant magistrate.

The case demonstrates that approval from Beijing was more than a mere formality, especially in cases where the suggested candidate did not fully conform to prevailing standards. Emperors forwarded memorials to the Board of Personnel, which competed with provincial governments over local appointment powers. The outcome was not a foregone conclusion; even if the majority of transfer proposals were approved, governors needed to keep in mind the possibility of being denied. This explains the elaborate memorials justifying the governor's choice. While an inflexible and mechanical process determined the appointment of magistrates in routine counties, in priority counties the provincial governor stood at the beginning of a genuinely deliberative appointment process.

The case also shows that the appointment procedure allowed for exceptions. This was important, because otherwise the pool of potential candidates from which the governor could choose would have been extremely small. In a province like Shandong with 107 counties, out of which 31 were priority counties, the pool consisted of three people per position, in theory. In practice, the pool was much smaller: some officials had not completed three years of service, others were not physically fit or were away during mourning periods, and still others were under impeachment. The governor had less discretion than the term "appointment privilege" seems to imply. Therefore, governors routinely memorialized Beijing to seek exceptions from the many rules. Instead of simply managing lists of lottery candidates, the Board had to decide when to grant exceptions and when to insist on enforcing precedents. As human decision-making replaced the lottery, not only the governor, but also the Board of Personnel saw an increase in its power.

Finally, participation of key provincial officials working under the governor, such as the administrative and surveillance commissioners, in the official selection procedure was the norm. When governors sent memorials concerning county magistrate appointments, they highlighted the participation of the two commissioners and occasionally of other officials as well. The provincial administrative commissioner in particular had firsthand experience from many counties, because he conducted audits and investigations. For example, when a magistrate died in office, the commissioner spent time checking accounts to uncover the reasons for the official's death. Given these duties, the two commissioners brought substantial local knowledge into deliberations on personnel selections.

\section{The Size of Local Government}

The size of local government varied drastically. While most counties operated with a handful of officials, some county governments were much bigger. Yanggu County had a big government, where the county magistrate could rely on a dozen subordinate officials: Apart from his assistant, there was a Confucian scholar in charge of education, along with a subdirector for schools. An inspector took care of petty professions. The county office 
had its own physician. There were supervisors of Buddhist and Daoist priests. Three officials were in charge of the complex system of sluice gates, which made the county indispensable in the geography of the empire. Even in the absence of formal rules stipulating the number of officials in a priority county, post designations guided the everyday decision-making by officials in Beijing and in the provinces, and they allocated bureaucratic resources to localities depending on their priority status. Priority labels thereby affected the size of local government.

The presence of just a few more officials stationed in a county made a significant difference, because subordinate officials were key agents of local government. I define "subordinate officials" as the group of individuals holding official positions below the magistrate level, yet still formally part of the state apparatus. Little is known about these subordinate officials, since historians have focused either on the preeminent figure of the magistrate or on clerks and runners (Reed 2000). According to conventional wisdom, the only significant local official was the magistrate, while his official subordinates were few, ineffective, and insignificant (Qu 1962, 9-13). But this view is not entirely accurate. First, the number of subordinate officials was substantial, and their responsibilities were critical. On average, a magistrate had at his disposition at least 3.4 subordinate officials (Watt 1972, 15). Many of them held so-called "educational posts," but their function was broader than the title suggests. For example, the principal of the geomancy school, or Yin-Yang School, was at the same time the inspector of petty professions (Hucker 1985, entry 8007), including itinerant fortunetellers, wizards, priests, street performers, midwives, firecracker makers, and musicians (Brunnert and Hagelstrom [1911] 1960 , entry 850A), in short, all sorts of potential trouble-makers in the eyes of the state. Many gazetteers list a supervisor of the Daoist priesthood, who kept a watchful eye on Daoist activities, thereby exercising social control over a segment of society known for its potentially regime-threatening secret societies (Liu Ping 2010, 395-96).

As figure 9 indicates, unlike clerks and runners, subordinate officials were rotated among counties and therefore formed part of a county's "expat community." They surely would have self-identified as outside officials close to the magistrate, and would have felt distant from local runners and even the local elite. Since their tenure was

\begin{tabular}{l|ccccc}
\hline \hline & Enxian & Tancheng & Guantao & Zhanhua & Dingtao \\
\hline Post Designation & CFPN & CFN & CF & N & none \\
\hline Magistrate & 3.0 & 3.3 & 3.4 & 2.4 & 3.0 \\
Assistant Magistrate & 4.4 & 5.9 & & & \\
Registrar & 8.8 & & 4.8 & & \\
Sub-District Magistrate & & & & 5.8 & \\
Jail Warden & 6.0 & 8.4 & 6.1 & 7.2 & 5.3 \\
Post Master & 6.6 & & & & \\
Director of Schools & 5.7 & 6.5 & 10.1 & 7.6 & 7.4 \\
Sub-Director of Schools & 3.0 & 5.9 & 5.7 & 8.3 & 6.9 \\
\hline \hline
\end{tabular}

Figure 9. Average length of tenure of officials in five selected counties. Method of calculation: Divide the number of years covered by the gazetteer by the number of individuals listed for each post. Since some individuals might be omitted, these numbers should be considered as upper bounds. Gazetteers from Zhongguo fangzhi congshu (1968-76). 


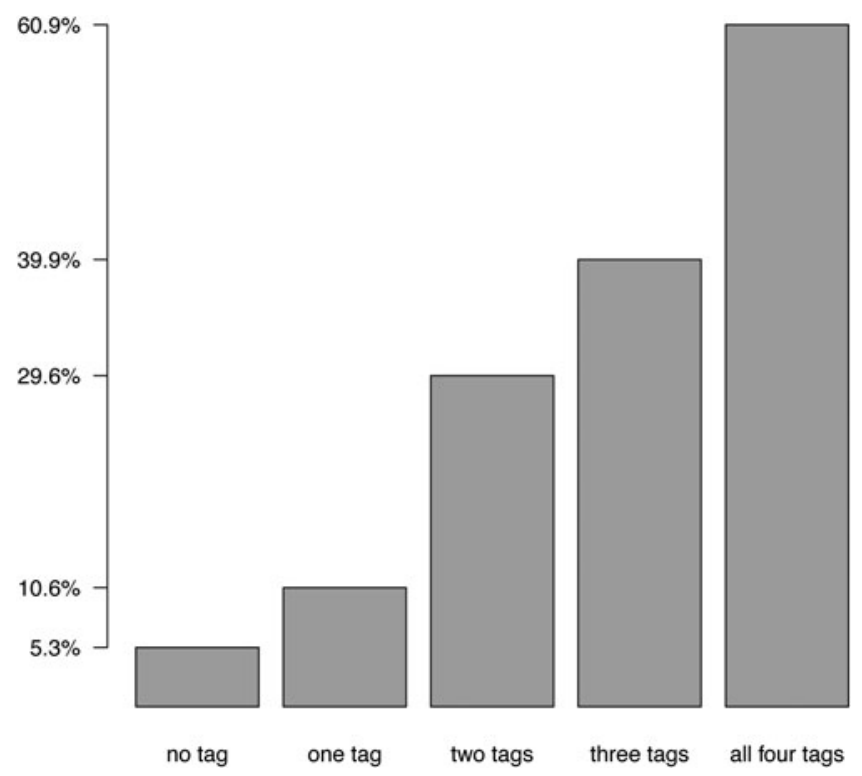

Figure 10. Proportion of counties with an assistant magistrate.

longer than the tenure of a magistrate, they could brief a newly arrived magistrate on local politics and intrigues. In cases when the magistrate had just passed the imperial exam and had no prior experience in administration, the role of the subordinate officials was critical. Subordinate officials played a key role in the socialization process of a new official into the imperial bureaucracy. Assistant magistrates were especially close to the magistrate. They could be received in audience by the emperor, and could be promoted to a magistrate position. The court in Beijing and the emperor himself dealt with issues pertaining to subordinate officials. In the Palace Museum collection of secret palace memorials, reserved for the most vital communications, we find no fewer than 722 memorials concerning assistant magistrates. One such memorial from 1764, for instance, proposes stationing the hapless assistant magistrates of Yishui County in a vast, banditinfested mountainous area (NPM 403021340). Indeed, subordinate officials were pivotal agents of local government.

The Imperial History Office compiled a list of changes in personnel assignments during the Qianlong era (NPM 211000105). Without exception, all reassignments of assistant magistrates in Shandong followed the post designations. Assistant magistrates left posts with two or fewer tags and were reassigned to posts with three or four tags. The magistrate of Leling County (two tags) lost his assistant, who was instead reassigned to Huimin County (three tags). The assistant magistrate from Zouping County (one tag) was transferred to Changqing County (four tags) on a busy north-south highway. The assistant magistrate from Huang County (one tag) moved to En County (four tags). In 1768-69, Juye County lost not only one post designation (two tags remained), but also its subdistrict magistrate. Instead, at the same time, a subdistrict magistrate was assigned to Heze County (three tags).

To confirm the hypothesis that county governments with more tags were bigger, I used the Qing Statutes to identify counties that had an assistant magistrate at the end of the 
Qing dynasty (Kun 1899, 5:3a-5:5a). By that time, post designations had shaped the allocation of personnel for two centuries. Altogether, the Qing court dispatched assistant magistrates to 347 counties. As it turns out, the higher the priority of a county, the more likely it was to have an assistant magistrate. The likelihood of an assistant magistrate ranged from 5 percent in routine counties to 60 percent in top-priority counties. Among counties with two tags, 30 percent had an assistant magistrate (see figure 10). Every additional tag mattered. The higher a county was on the list of governing priorities, the greater the presence of civilian administration.

\section{Conclusion}

China's imperial rulers defined territorial priorities, flagging jurisdictions that deserved special state attention. These priorities then came to define imperial state presence in each locality. As a good first approximation, one could describe this as a binary approach, differentiating between priority and routine counties. Priority counties tended to be situated along important travel routes with lots of official business and be known for a difficult population that was slow to pay taxes. Appointments to priority posts were the result of a rational-deliberative process, whereas in routine counties magistrates were chosen by a mechanical process that left much to sheer luck. But the system was more complex than this binary suggests. The intensity of state presence, measured in this article as the likelihood of having an assistant county magistrate, increased with each additional priority marker, allowing for five importance levels. Priority markers even provided personnel planners with guidance as to the nature of local challenges.

One implication for research on Qing local administration is that routine counties and priority counties should not be evaluated on the same terms. Attempts to describe a typical, or even representative, county administration are problematic. If one asks whether local government during the Qing dynasty was "big" or "small," it is necessary, at the very least, to distinguish the vast majority of routine counties from the smaller, yet important set of priority counties. Averaging out differences between the two kinds of counties, one may end up with a statistical artifact that bears little resemblance to most counties as they actually existed. Moreover, computing averages obscures a key feature of Chinese statecraft, historical as well as contemporary: the lack of uniformity is not a bureaucratic imperfection; it reflects a strategy of differentiated government.

The evolution of the post designation system is largely consistent with views of imperial China's bureaucracy as highly institutionalized, undergoing modernization in the eighteenth century and then backsliding in the nineteenth century. Yet categories of modernity fail to fully capture the complexity of the process. Assigning priorities was a form of modern simplification in the sense of standardizing extremely diverse local government challenges. Acting on priorities by differentiating governance challenges is a form of bureaucratic specialization. Replacing the lottery that left personnel management to "divine will" by a deliberative process was "rational." At the same time, there was a flipside to bureaucratic modernization under the Qing. Un-Weberian corruption appeared when human discretion replaced mechanical and random selection. Although there were good political reasons for letting the defective traditional appointment system coexist with the more progressive method, this hybridity hindered rational personnel allocation. Formalized institutionalization at the same time made the system unresponsive to 
new circumstances, raising the question of why the court was unable or unwilling to reform. Finally, territorial priorities reinforced differences, subverting the modern ambition for uniform control. Emperor Yongzheng settled on a second-best solution, given political and practical constraints.

Political scientists have explored state-building with minimal attention to subnational variation in the territorial reach of the state. The existence of areas with a low state presence—sometimes called "brown" areas (O’Donnell 1993, 1359)—is well known, but we lack an analysis of how the location and extent of these areas may be a result of statebuilders' strategic calculations. In the case of China, where was the state weak and where did it deploy its most potent administrative resources? The first counties that Yongzheng elevated to priority status were jurisdictions along important waterways, such as counties that were vital for maintaining the Grand Canal. This is reminiscent of Karl Wittfogel's $(1963,49)$ thesis that hydraulic operations fostered strong states. Yet the kind of hydraulic operations that made a county worthy of attention had less to do with irrigation and flood control, which Wittfogel highlights, than with operations to maintain longdistance communication and transportation infrastructure. That is, state-builders' governing priorities were geared not toward agricultural needs, but toward the needs of the centralized state. In addition, when counties with importance to the central state had hard-to-govern populations, state-builders would not retreat. Instead, the local priority system enshrined the principle of deploying more resources precisely to places where tax collection was difficult, where the population was unruly and violence was customary. Bigger civilian local governments with experienced officials would be found in places considered as vital pillars for empire-wide communication and known for governability problems. The heterogeneity of Chinese local government was by no means an accidental result of forces beyond the control of the court, but rather a consciously designed system that broke free from topographically predetermined core-periphery divides.

Differentiated government based on priorities is a powerful tool of Chinese statecraft, deeply rooted in the bureaucratic tradition. It is also a hallmark of other empires, from the Roman Empire to the British Empire, which could only maintain their large sizes thanks to well-specified priorities and a "politics of difference" (Burbank 2010, 11). Cases such as the Ottoman Empire highlight how a diverse multiplicity of institutions and governance strategies coexisted within the same state (Barkey 2008, 277). Although in less diverse and smaller states a more radical quest for uniformity would be less costly, even there central state-builders do not aspire to uniformly powerful control, as demonstrated by the rulers of Tokugawa Japan (1603-1868), who weighed the tradeoffs before deciding which regions could be administered by potentially hostile feudal lords, and which ones had to be administered by particularly trusted lords or even remain under direct imperial control (Hall 1999, 343). State-builders vary both in terms of the ambition for standardization and in terms of their ability to shape institutional diversity in their own interest, rather than living with historically predetermined patterns. Compared to state-builders elsewhere, the Qing court stands out for explicitly recording its strategic calculus and for the unusually institutionalized process that led to the definition of fine-grained priorities.

The challenges of selecting local officials in imperial China bear a striking resemblance to the challenges of managing personnel in China today. In the absence of democratic elections, the fundamental task of appointing capable and loyal officials while avoiding corruption remains unchanged. Nowadays, China's priority counties are referred 
to as "the 100 strong counties." The Communist Party's Organization Department appoints particularly competent and reliable cadres as party secretaries of these counties. As in imperial China, the priority of a county is determined based on four separate components, although instead of Chinese characters, letters are used as in U.S.-style creditrating systems. The strategic challenges remain similar, and so do the statist solutions to solve them. It is no coincidence that the Organization Department, alongside books on party organization, publishes research on imperial-era personnel administration (An 2011). Then as now, central authorities carefully define their priorities.

The reform of the personnel system, henceforth identifying and prioritizing the realm's vitally important jurisdictions, must be added to the list of path-breaking administrative reforms by Emperor Yongzheng, which also includes new bureaucratic communication channels, the establishment of the Grand Council, and ambitious fiscal reforms (Bartlett 1991; Thornton 2007, 22n2). Post designations were motivated by the ruler's concern with personnel policy, which also led Yongzheng to innovate in areas such as imperial audiences (Wang 2007) and official sick leave (He 2012). Yongzheng's reforms shaped the Qing bureaucracy for two more centuries. The priority ratings even survived Qing rule. After a revolution had ended the Qing dynasty in 1911, succeeding governments not only continued assigning priorities, distinguishing among four classes of counties, but also expanded the implications of the classification. Governing priorities determined the size of local militias (German Foreign Ministry Archive, Tsingtau 20-1, March 5, 1932) and set standards for public goods provision (Hubei Archive LS1-1-779). Under the People's Republic, the establishment of autonomous regions, the "third front" development strategy, the "one country, two systems" formula, the opening of special economic zones, and the geopolitical selection of key projects indicate that the delimitation of territorial priorities and the differentiation of local government remain hallmarks of Chinese governance in the twenty-first century.

\section{Acknowledgments}

For helpful comments and support, I am grateful to Sana Aiyar, M. Lex Berman, He Bian, Hsi-yuan Chen, Miao-fen Chen, Stephen Ford, Chin-shing Huang, Kyle A. Jaros, Ya-ling Lee, Jie Li, Cheng-yun Liu, Ping Liu, Yanjun Luo, Xiaohe Ma, Elizabeth J. Perry, Daniel M. Smith, Michael Szonyi, Rudolf G. Wagner, Pierre-Étienne Will, and three anonymous reviewers; as well as to the staff at the Number One Historical Archives, Academia Sinica, and the National Palace Museum. For their financial support, I thank the Harvard University Asia Center and the Fairbank Center for Chinese Studies.

\section{List of References}

\section{Archives}

AS: Ming Qing Archive at Academia Sinica, Taipei.

FC: Number One Historical Archive in the Forbidden City, Beijing.

NPM: Library of the National Palace Museum, Taipei. 


\section{Other Sources}

An Zuozhang, ed. 2011. Zhongguo Libu yanjiu [Studies on China's Board of Personnel]. Beijing: Dangjian duwu chubanshe.

Barkey, Karen. 2008. Empire of Difference: The Ottomans in Comparative Perspective. Cambridge: Cambridge University Press.

Bartlett, Beatrice S. 1991. Monarchs and Ministers: The Grand Council in Mid-Ch'ing China, 1723-1820. Berkeley: University of California Press.

Boone, Catherine. 2012. "Territorial Politics and the Reach of the State: Unevenness by Design." Revista de ciencia politica 32(3):623-41.

Brenan, Byron. 1899. The Office of the District Magistrate in China. Shanghai: Mercury Office.

Brunnert, H. S., and V. V. Hagelstrom. [1911] 1960. Present Day Political Organization of China. Taipei: Book World.

Burbank, Jane. 2010. Empires in World History: Power and the Politics of Difference. Princeton, N.J.: Princeton University Press.

Esherick, Jospen W. 1987. The Origins of the Boxer Uprising. Berkeley: University of California Press.

Guy, R. Kent. 2010. Qing Governors and Their Provinces: The Evolution of Territorial Administration in China, 1644-1796. Seattle: University of Washington Press.

— 2014. "Routine Promotions: Li Hu and the Dusty Byways of Empire." In The Dynastic Centre and the Provinces: Agents and Interactions, eds. Jeroen Frans Jozef Duindam and Sabine Dabringhaus, 74-93. Leiden: Brill.

Hall, John Whitney. 1999. Government and Local Power in Japan, 500 to 1700: A Study on Bizen Province. Ann Arbor: University of Michigan Press.

He Bian. 2012. "Too Sick to Serve: The Politics of Illness in the Qing Civil Bureaucracy." Late Imperial China 33(2):40-75.

Hucker, Charles O. 1985. A Dictionary of Official Titles in Imperial China. Stanford, Calif:: Stanford University Press.

I Songgyu and Joshua A. Fogel. 1981. "Shantung in the Shun-chih Reign: The Establishment of Local Control and the Gentry Response." Ch'ing wen-t’i 4(5):1-31.

Kun Gang, ed. 1899. Daqing huidian 大清會典 [Statutes of the Qing]. Beijing: Waijiao bu.

Kutcher, Norman. 1999. Mourning in Late Imperial China: Filial Piety and the State. Cambridge: Cambridge University Press.

Liu Ping. 2010. A History of Chinese Secret Religious Cults. Beijing: Beijing Daxue chubanshe.

Liu Zhengyun. 1993. "Chong, Fan, Pi, Nan: Qingdai dao fu ting zhou xian dengji chushen" [Chong, Fan, Pi, Nan: Exploration of the classification system for circuits, departments, counties during the Qing dynasty]. Zhongguo yanjiuyuan lishi yuyan yanjiusuo jikan 64(1):175-204.

— 1994. "A Revision to the Post Designations in the 'Treatise on Geography' of the Ch'ing-shih kao.” Bulletin of the Institute of History and Philology, Academia Sinica 65(3):509-14.

- 2012. Archival Documents from the Ming-Qing Era. Taipei: Humanities Center of Chengchi University.

Masui Yasuki. 1999/2000. “Shindai 18-shō ni okeru 'Pekin shutoken' no chihō gyōsei kanri-jō no tokushitsu" [Provincial administration of "Beijing Metropolitan Area" in the context of the Qing dynasty's 18 provinces]. Hōsei riron 32(1):14-36 and 32(3/4):128-248. 
Metzger, Thomas A. 1973. The Internal Organization of Ching Bureaucracy: Legal, Normative, and Communication Aspects. Cambridge, Mass.: Harvard University Press.

Naquin, Susan. 1981. Shantung Rebellion: The Wang Lun Uprising of 1774. New Haven, Conn.: Yale University Press.

Nimick, Thомas G. 1999. "The Placement of Local Magistrates in Ming China." Late Imperial China 20(2):35-60.

O’Donnell, Guillermo. 1993. “On the State, Democratization and Some Conceptual Problems: A Latin American View with Glances at Some Postcommunist Countries." World Development 21(8):1355-69.

Perry, Elizabeth J. 1980. Rebels and Revolutionaries in North China, 1845-1945. Stanford, Calif.: Stanford University Press.

Pomeranz, Kenneth. 1993. The Making of a Hinterland: State, Society, and Economy in Inland North China, 1853-1937. Berkeley: University of California Press.

Qin Guojing, Tang Yinian, Ye Xiuyun, and Zhang Guisu. 1997. Zhongguo di yi lishi dang'an guancang Qingdai guanyuan lvli dang'an quanbian [Complete edition of Qing officials' CVs from the China No.1 Historical Archive]. Shanghai: Huadong Shifan Daxue chubanshe.

QINGDAI JINSHEN LU JiCHENG [COLLECTION OF LisTS OF OFFICIAL POSITIONS FROM THE Qing DYNASTy]. 2008. Zhengzhou: Daxiang chubanshe.

Qu Tongzu. 1962. Local Government in China under the Ch'ing. Cambridge, Mass.: Harvard University Press.

Reed, Bradly W. 2000. Talons and Teeth: County Clerks and Runners in the Qing Dynasty. Stanford, Calif.: Stanford University Press.

Scott, James C. 1998. Seeing Like a State: How Certain Schemes to Improve the Human Condition Have Failed. New Haven, Conn.: Yale University Press.

Skinner, G. William. 1977. "Cities and the Hierarchy of Local Systems.” In The City in Late Imperial China, ed. G. William Skinner, 275-351. Stanford, Calif.: Stanford University Press.

—. 1985. "Presidential Address: The Structure of Chinese History." Journal of Asian Studies 44(2):271-92.

Skinner, G. W., Zumou Yue, and Mark Henderson. 2013. "China-CPZ (Core Periphery Zones).” G. W. Skinner Data Archive, http://hdl.handle.net/1902.1/20640 (accessed October 28, 2016).

Soifer, Hillel. 2008. "State Infrastructural Power: Approaches to Conceptualization and Measurement." Studies in Comparative International Development 43(3-4): 231-51.

Sun BaOtian et al. 1915. Shandong tongzhi [Shandong gazetteer]. Shandong: Tongzhi kanyin ju.

Sutton, Donald S. 2007. "Ritual, Cultural Standardization, and Orthopraxy in China: Reconsidering James L. Watson's Ideas.” Modern China 33(1):3-21.

Thornton, Patricia M. 2007. Disciplining the State: Virtue, Violence and State-Making in Modern China. Cambridge, Mass.: Harvard University Press.

Tsai, Lily L., and Daniel Ziblatt. 2009. "The Rise of Subnational and Multilevel Comparative Politics." Working paper.

WAng Zhiming. 2007. Yongzheng chao guanliao zhidu yanjiu [The personnel system of the Yongzheng era]. Shanghai: Shanghai chubanshe.

Watt, John R. 1972. The District Magistrate in Late Imperial China. New York: Columbia University Press. 
Will, Pierre-Étienne. 2002. "Creation, Conflict, and Routinization: The Appointment of Officials by Drawing Lots, 1594-1700.” Ming Qing Yanjiu, 73-121. Napoli: Università degli Studi di Napoli "L’Orientale."

Wittfogel, Karl A. 1963. Oriental Despotism: A Comparative Study of Total Power. New Haven, Conn.: Yale University Press.

Yongzheng Chao Neige Liuke Shishu: Li Ke [Records of the Six Boards of the Grand Secretariat during the Yongzheng reign: Board of Personnel]. 2002. Guilin: Guangxi Shifan Daxue chubanshe.

Yu Bingkun and Zhang Shucai. 1994. Selected Files Concerning the Punishment of Corruption during the Qianlong Reign. Beijing: Zhonghua shuju.

Yue Zumou, G. William Skinner, and Mark Henderson. 2007. "ChinaW Dataset: Nineteenth-Century Cities, Yamens, and County-Level Units.” CHGIS Datasets V4, www.fas.harvard.edu/ chgis/data/chgis/downloads/v4/datasets/ (accessed November 28, 2016).

Yun TAO, ed. 1764. Daqing huidian zeli 大清會典則例 [Statutes and precedents of the Qing]. Beijing: Wuying dian.

Zhang, Lawrence L. C. 2010. "Power for a Price: Office Purchase, Elite Families, and Status Maintenance in Qing China.” PhD diss., Harvard University.

Zhang Zhengguo. 2012. "Qingdai dao, fu, ting, zhou, xian dengji zhidu de queding” [Priority assignments to circuits, prefectures, subprefectures, departments, and districts during the Qing]. Ming Qing luncong 11:382-400.

ZhongGuo fangzhi congshu [Series of Chinese local gazetteers]. 1968-76. Taipei: Chengwen chubanshe. 